\title{
NEW IDEAS ABOUT THE BALKAN PENINSULA EAST PART MORPHOTECTONICS
}

DOI: http://dx.doi.org/10.18509/GBP.2020.02 UDC: 551.43:551.248(292.464)

\author{
Tzanko Tzankov ${ }^{1}$ \\ Svetla Stankova ${ }^{2}$ \\ Milena Stoyanova ${ }^{2}$ \\ ${ }^{1}$ South-West University „Neofit Rilski“ - Blagoevgrad, Bulgaria \\ ${ }^{2}$ Konstantin Preslavsky University of Shumen, Bulgaria
}

\begin{abstract}
The article introduces the results of the author's new investigations about the origin, Quaternary morphotectonic evolution and the modern morphostructure of the Bulgarian Continental Microplate from the eastern part of Balkan Peninsula.

The research was realized on a base of the contemporary Plate tectonic study principia by means of the morphostructural analysis apply. It was provided the principal relief building role of the regional mosaic pattern and the listric faulting in the Balkan Peninsula East Part.
\end{abstract}

Keywords: Ocean Closing, Archipelago, New Europe, Mosaic pattern, Transcontinental Collision, Quaternary Relief

\section{INTRODUCTION}

The results of the author's investigations [1], [2], [3], [4], [5], [6], [7], [8], [9] et al. about the origin, Quaternary morphotectonic evolution and the modern morphostructure of the Balkan Peninsula East Margin is given the possibility for the regional complex characteristic of the morphotectonic and morphostructural pattern of the mentioned area. The research was realized on a base of the contemporary Plate tectonic study principia by means of the morphostructural analysis apply. The particularity of the morphotectonic and morphostructural regional peculiarities depends from the investigation scale. The proposed first overview concerns the first rare morphounits only.

\section{Investigation object}

The Balkan Peninsula East Part is limited from the Lower Danube to the north, the Black Sea West Margin to the East, the Marmara Sea and the Aegean Sea (White Sea), the Lower Struma River, the Butkovo and the Doyran Lakes to the South and the Vardar, the Pchinya, the Morava and the Timok Rivers to the West (Fig. 1, 2). The very varied and quickly changeable relief of this area includes high mountains (the Rila, the Pirin, the Rhodopes, the Vitosha), the Chain Mountains (the Stara Planina, the Sredna Gora), middle and low high mountains, low lands, planes many kettles. 


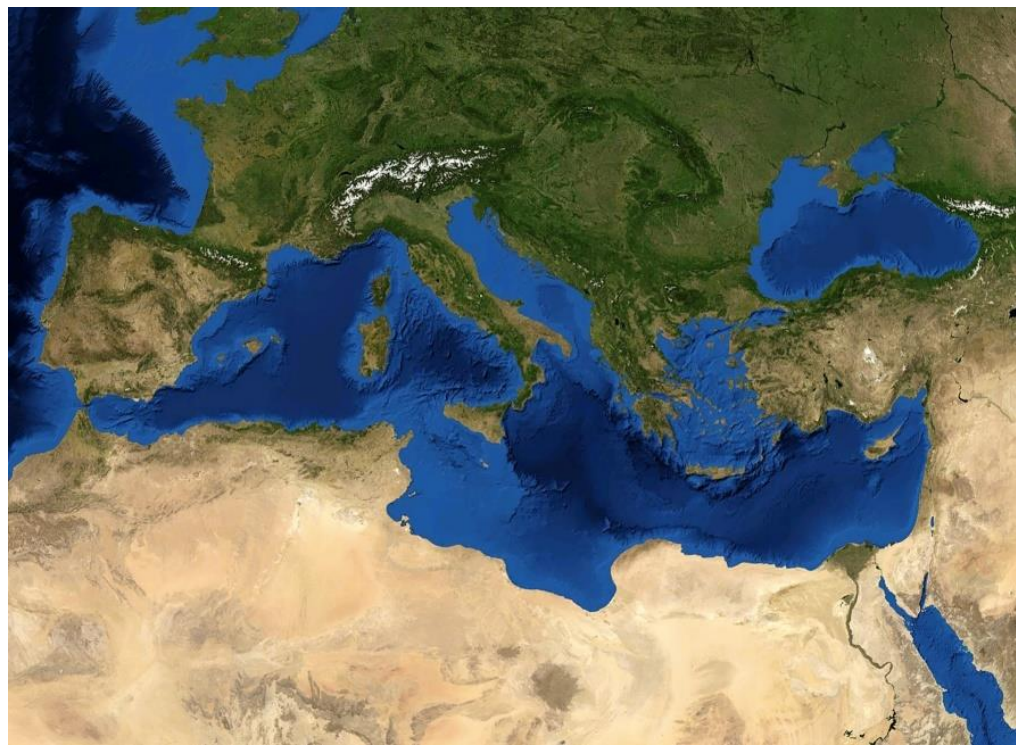

Figure 1. The Balkan Peninsula - geographical position

\section{About the Phanerozoic Tectonic Evolution}

The East Balkan Peninsula Area was a part from the Tethys Ocean North West End until 72000000 years (Fig. 2). During the Jurassic - pre Maestrichtian Geologic-Tectonic Evolution in the responded part of the Tethys Ocean North West End was disposed the Intra Mediterranean Archipelago (Fig. 2, 3). The last one was composed by numerous different big islands - fragments from the Gondwana (Africa) Continental Massif North Margin. Every one of them distinguished by more or less specific Jurassic-Campanean Geologic-Tectonic Pattern (Fig. 4). The mentioned continental fragments have moved to the Paleo Europe Continental Massif during the Tethys Ocean Subduction (Fig. 5). They are accumulated near the Paleo Europe South Margin and formed the New Europe Continental Massif (Fig. 5). The East part of the neo builder Balkan Peninsula is formed from the Moesian (it South part), Bulgarian and Halkidikian Continental Microplates (Fig. 6). Its primary low land relief corresponds with the Maestrichtian -Early Pleistocene Orthoplain.

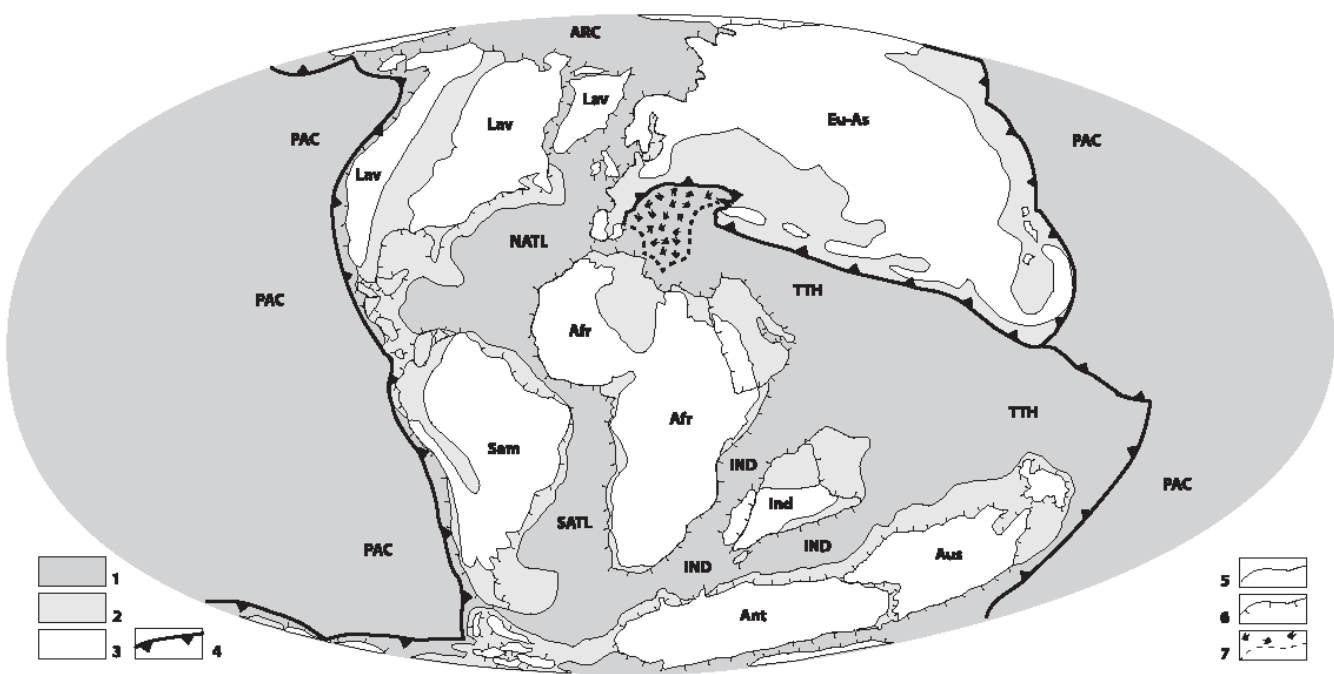

Figure 2. Provisional sketch of the Mediterranean Area during the Late Cretaceous (Coniacian-Santonian) West End Tethys Ocean Closing 
1 - ocean, 2 - epicontinental basin, 3- continent, 4- continental margin, 5- subduction, 6 - collision, 7Intra Mediterranean Archipelago Zone. Oceans: PAC- Pacific, NATL- North Atlantic, SATL- South Atlantic, IND- Indian, ARC- Arctic, TTH - Tethys. Most continental massifs: Lav - North America (Lawrencia) (Proto Laurasia), Eu-As - Euro-Asia (Proto Laurasia), Sam - South America (Proto Gondwana), Afr - Africa (Gondwana), Ind - India (Proto Gondwana), Ant - Antarctica (Proto Gondwana), Aus - Australia (Proto Gondwana)

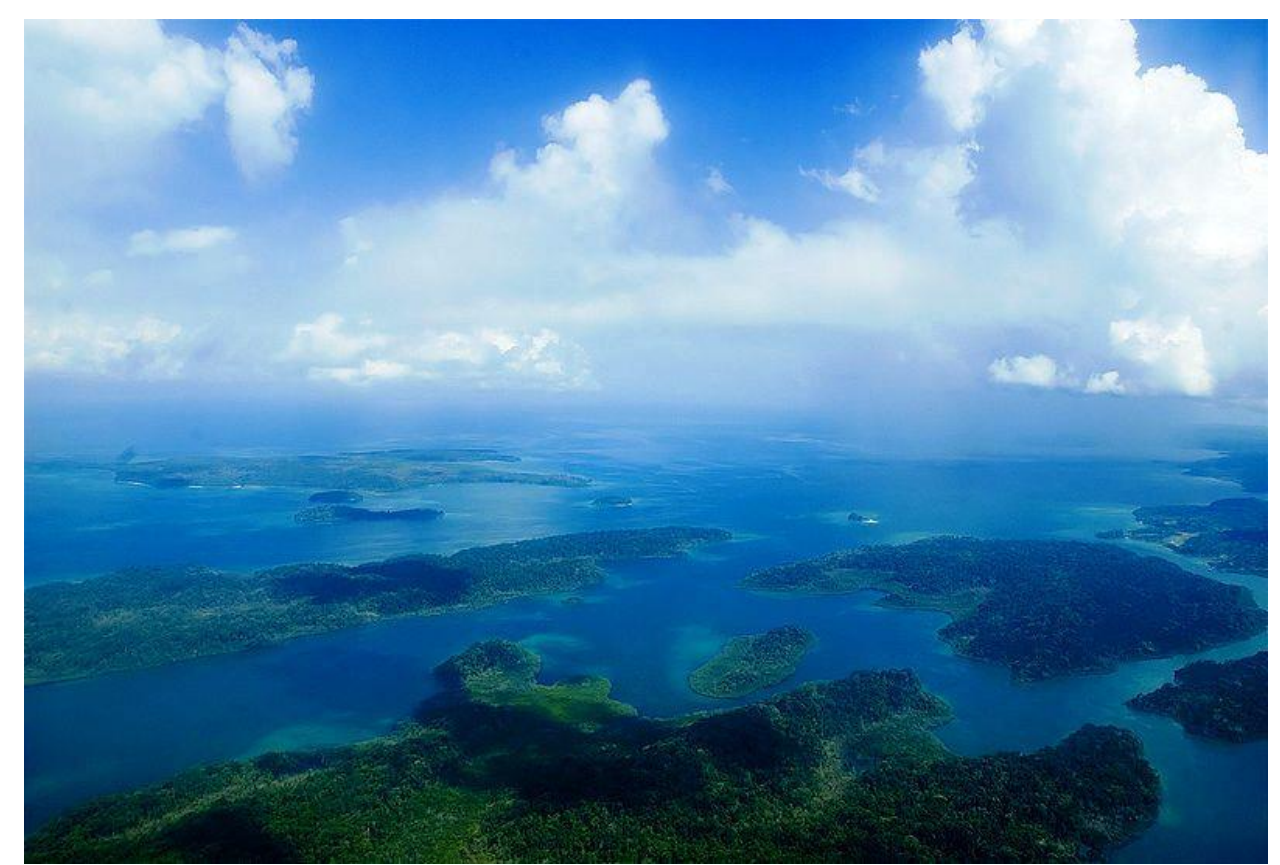

Figure 3. Hypothetical overview of one Intra Mediterranean Archipelago Part (before 72000000 years)

The modern East Balkan Peninsula relief is forming during the Late Pleistocene Holocene Time.

The Quaternary Earth superficial relief building processes was and are predominantly provoked and controlled by the Upper Mantle - Asthenosphere energy. Its Earth superficial effects are expressed by the relationships between the seismic effects and the regional faulting.

The East Balkan Peninsula Margin coincides with the border between the Bulgarian and Moesian Continental Microplates from the west and the Black Sea Oceanic Microplate to the east. This border present the Neo Europe West Passive Continental Margin in the area of the last Tethys Oceanic Fragment - it Black Sea Oceanic Gulf.

The modern East Balkan Peninsula Relief is forming during the Late Pleistocene Holocene Time.

The Quaternary Earth superficial relief building processes was and are predominantly provoked and controlled by the Upper Mantle - Asthenosphere energy. Its Earth superficial effects are expressed by the relationships between the seismic effects and the regional faulting. 


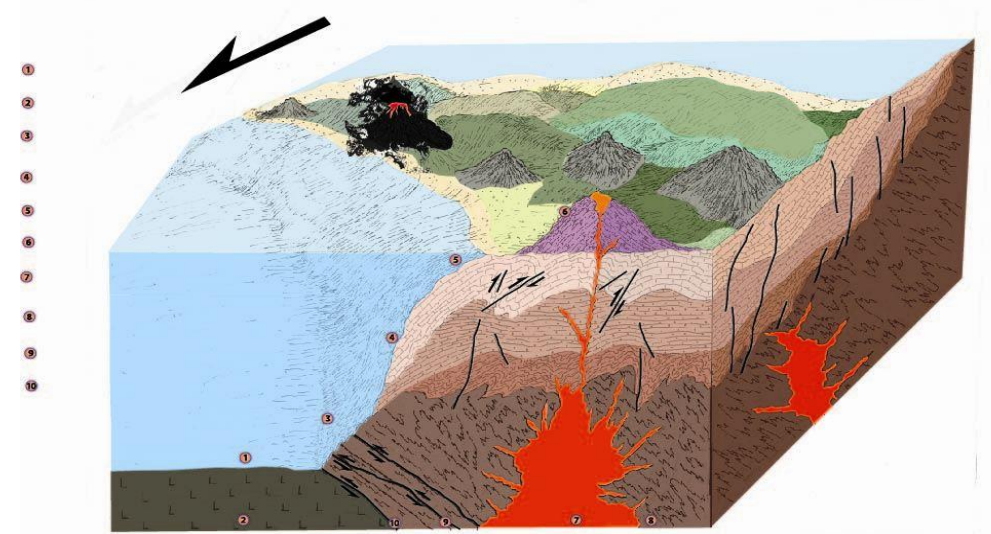

Figure 4. Block diagram model of the Gondwana Continental Fragments (belong to the Mediterranean archipelago) Internal Pattern in the Tethys Ocean

1 - Oceanic bottom, 2 - oceanic crust, 3 - continental foot, 4 - continental slope, 5 - shelf, 6 - volcano

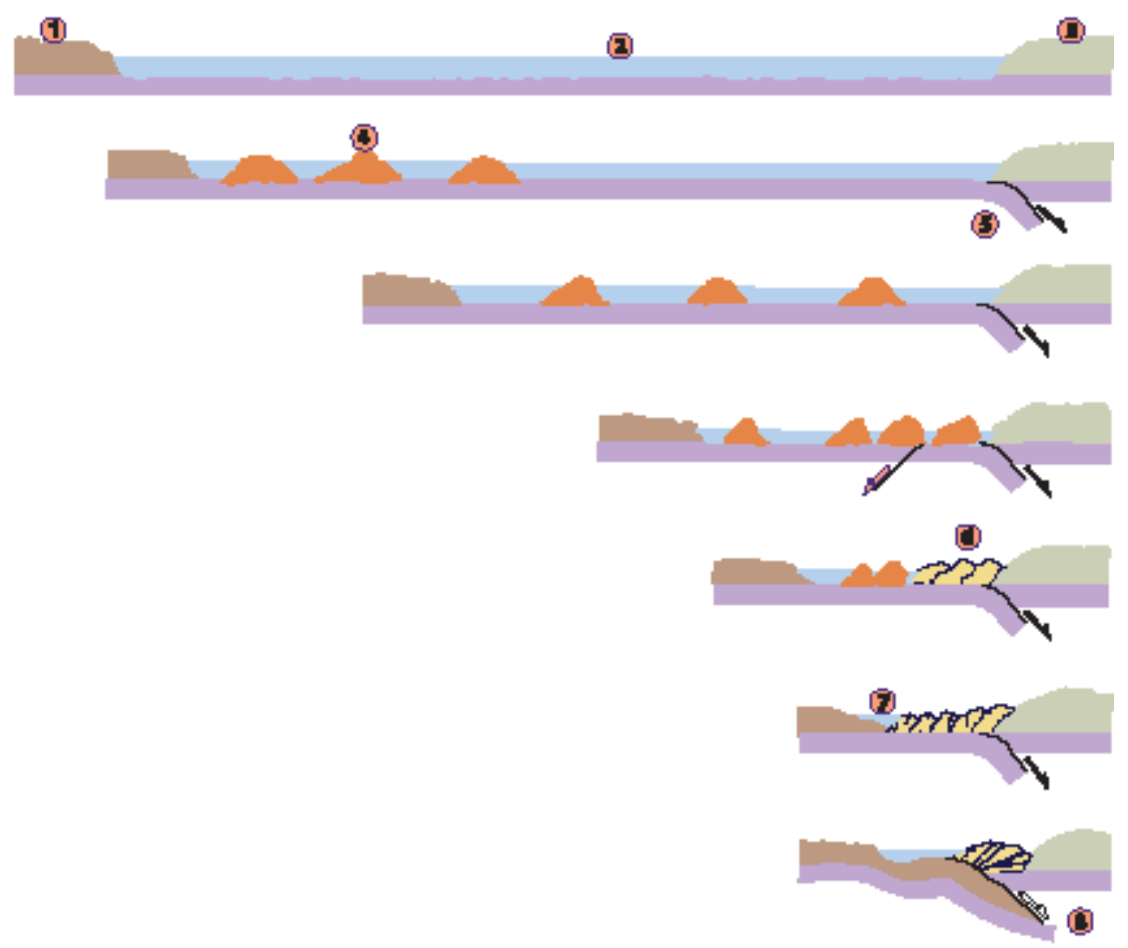

Figure 5. Moments from the Tethys Ocean Closing (according to Tzankov)

1- Gondwana continental massif, 2- Tethys Ocean, 3- Paleo Europe Continental Massif, 4 - Gondwana Continental Crust Fragments in the Tethys Ocean - Intra Mediterranean Archipelago, 5 - Tethys Ocean Phanerozoic Subduction down the Paleo Europe Continental Massif, 6- Neo Europe Continental Massif Building 7- Mediterranean See Building (after the Tethys Ocean Closing), 8- intra continental collision between of the Gondwana and the Neo Europe Continental Massif 


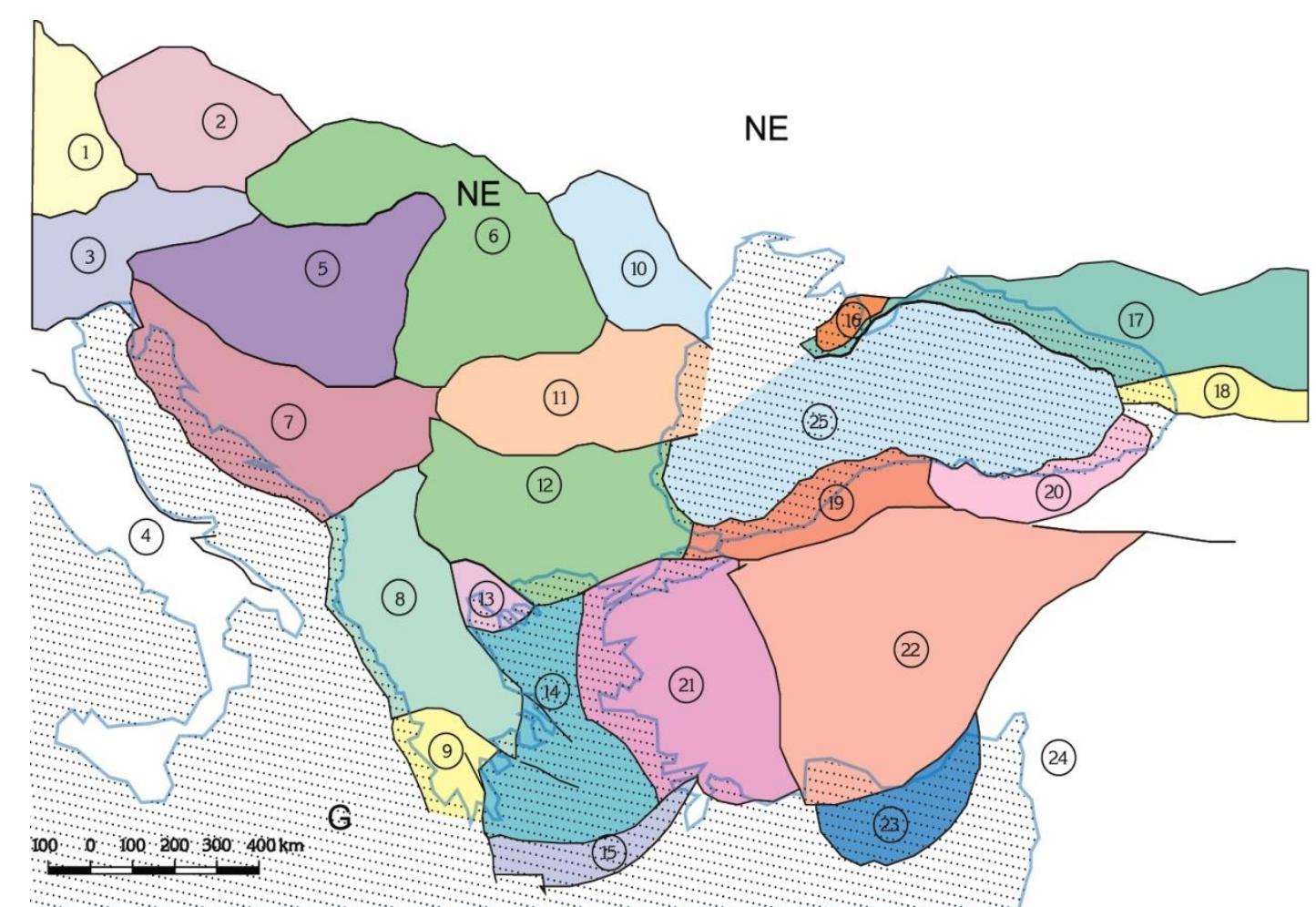

Figure 6. Mosaic pattern of the Neo European Continental Massif South-East Part (last 72000000 years) 1-23 - continental microplates: 1- Bavarian, 2- Bohemian, 3- Alpean, 4-Apeninian, 5-

Moravian, 6- Carpathian, 7- Dinarian, 8- Pindian, 9- Heladian, 10- Skitian, 11-Moesian, 12- Bulgarian, 13- Halkidikian, 14- Aegean, 15- Cretean, 16- Creamean, 17- Caucasean, 18- Georgian, 19- West Pontidan, 20- East Pontidan, 21- West Anatolian, 22- East Anatolian, 23- Cyprian, 23- Arabian Plate; 25- Black Sea (Pontian) Oceanic Microplate

The East Balkan Peninsula Margin coincides with the border between the Bulgarian and Moesian Continental Microplates from the west and the Black Sea Oceanic Microplate to the east. This border present the Neo Europe West Passive Continental Margin in the area of the last Tethys Oceanic Fragment - it Black Sea Oceanic Gulf.

\section{Post Early Pleistocene Deformation Generations}

The regional morphostructural analysis of the Late Pleistocene-Holocene deformations in the eastern parts of the Balkan Peninsula shows the existence of the several simultaneous or consecutive manifested deformation processes. Every of them have produced specific morphostructural generation with different time and type of origin and evolution. The contemporary relics of those morphogenerations determined the peculiarities of the big parts of the modern relief. The solving of all those questions will be given the possibility for the complex explanation of the Quaternary regional morphosructural and morphotectonics setting in the eastern part of the Balkan Peninsula.

The Late Pleistocene beginning coincides with the sharp geodynamic activity increases in the eastern part of the Balkan Peninsula. It is thanks to the beginner transcontinental collision between the New Europe Mosaic Continental Massif and Gondwana Continental Massif. This process was provoked the step by step increased the destruction of the post Early Pleistocene Orthoplain. The new formed morphounits are result from brittle deformations. 


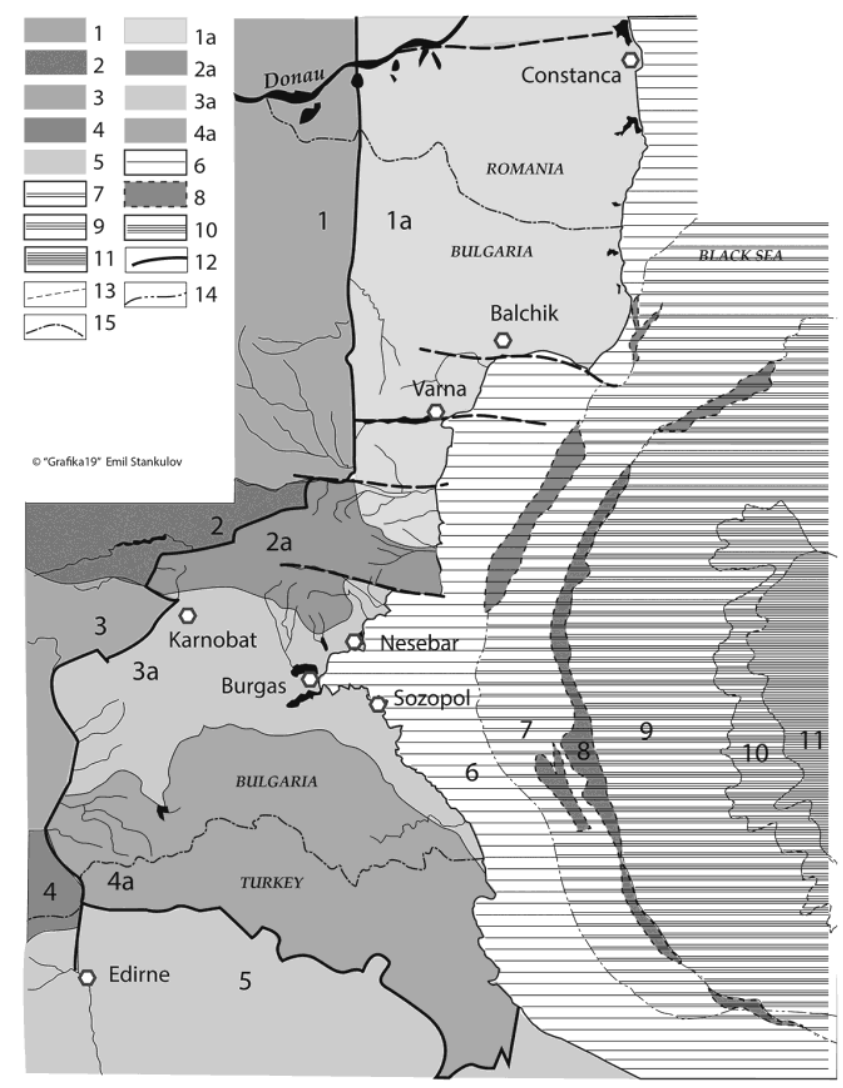

Figure 7. Survey morphostructural sketch of the West Black Sea Passive Continental margin 1-5 - subaerial margin area: 1-1a - the South Moesian Morphostructural Zone: 1- continental part, 1amargin part: 2-2a - the Hemus Morphostructural Zone: 1- continental part, 1a- margin part: 3-3a - the Upper Thracian Morphostructural Zone: 3- continental part, 3a- margin part: 4 - 4a - the Sakar-Strandzha

Morphostructural Zone Morphostructural Zone: 4- continental part, 4a- margin part: 5- the Lower Thracian Morphostructural Zone; 6-11 - subaqual margin area: 6-8 - continental shelf: 6- high step, 7down step, 8- fault zone; 9- continental slope, 10- continental foot, 11- the Black Sea Bottom; 12 - west border of the West Black Sea Passive Continental margin, 13- some important faults, 14- border between the morphostructural zones, 15 - boundary between Turkey and Bulgaria

The proved today continued uplifting of the predominantly mountainous relief from the southern sector of the eastern part of the Balkan Peninsula show the domination of the endogenous processes role by the contemporary relief building.

The origin of all of the morphogeneration is related determinate geodynamic processes in the upper Earth's crust parts.

The post Early Pleistocene comb-like morphostructures are result from the very weak epidermal bending of some Earth's superficial regions. They are forming the regional proto morphostructures of the responded orthoplain regions.

The Late Pleistocene concentric morphostructures marked the beginning of the endogenous deformations in the destructed orthoplain parts. Those morphounits were deep eroded and segmented from the regional fault net. Its traces are conserved in the separate Late Pleistocene-Holocene dome-like morphostructures.

The Late Pleistocene-Holocene dome-like morphostructures are formed in the rim of the crustal fragments, limited by the local fault net. They outline the principal after the endogen predetermined regional relief peculiarities. The giving a final touch of those morphounits is continuing today. 
The Holocene concentric arched mountain morphostructures are represented by the first rare ridges in the region. They marked zones with the maximal contemporary relief elevation.

\section{Regional morphotectonic pattern}

The East part of the Balkan Peninsula corresponds with the most south-east segment from the Neo Europe Mosaic Continental Massif. It regional morphostructure is composed be numerous fragments from the Late Pleistocene-Holocene dome-like morphostructures, Holocene concentric arched mountain morphostructures and the modern relics from the post Early Pleistocene Orthoplain. Those relics composed the modern complex morphostructural passages regional disposition within the Balkan Peninsula Eastern Part (Fig. 8).

The Balkan Peninsula East part includes the Bulgarian and Halkidikian Continental Microplates and the most south part from Moesian Continental Microplate - South Moesian Morphostructural zone (Fig. 6).

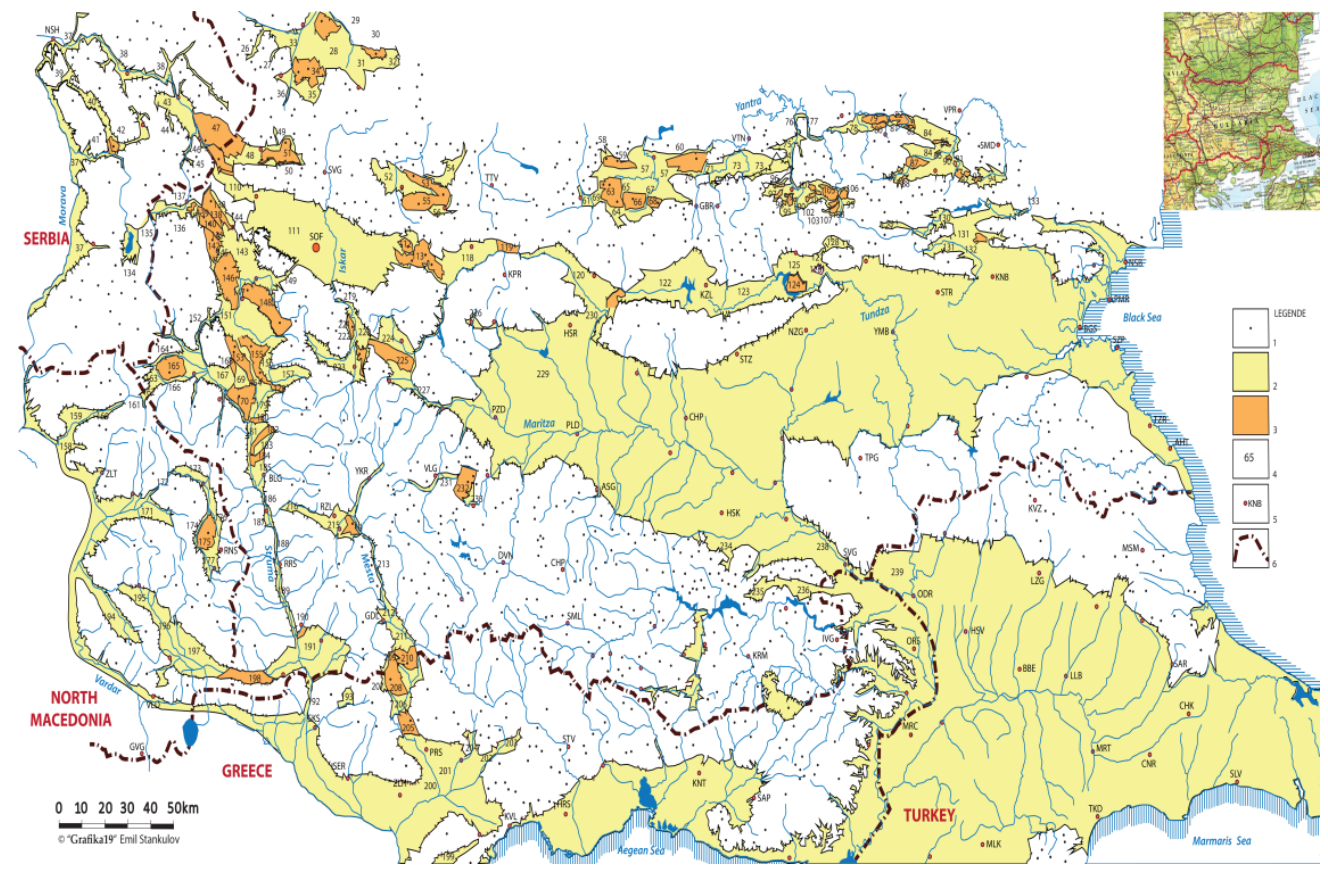

Figure 8. Survey map of the complex morphostructural passages regional disposition within the Balkan Peninsula Eastern Part

1- positive morphostructures with centers of maximal contemporary elevation (black points), 2-3negative morphostructures: 2- lowland, kettle and river valley morphostructures, 3-morphostructural thresholds; 4- number of negative morphostructure, 5- city and towns: AHT- Ahtopol, ASG- Asenovgrad, BGS- Burgas, BLG- Blagoevgrad, BBE- Babaeski, CHP- Chirpan, CHR- Chorlu, DVN- Devin, GBR-

Gabrovo, GDL- Gotse Delchev, GVG- Gevgeliya, HSR - Hisarya, HSV- Havsa, IVG- Ivaylovgrad, KNB- Karnobat, KNT- Ksanti, KRM- Krumovgrad, KVL-Kavala, LLB- Lyuleburgas, LZG- Lozengrad, MRC- Merich, MRT- Muratl, MSM- Demirkyoy, NSH-Nish, NSB- Nesebar, NZG- Nova Zagora, ODREdirne, PLD-Plovdiv, PMR-Pomorie, PRS-Prosechani, RNS-Bosilegrad, RZL-Razlog, SAP-Sape, SAR Saray, SER- Sere, SLV- Silivria, SMD- Smyadovo, SML- Smolyan, SOF-Sofia, STV- Stavropulis, SVGSvilengrad, SVG-Svoge, STZ- Stara Zagora, TKD- Tekirdag, TPG- Topolovgrad, TTV- Teteven, VLGVelingrad, VLD- Valandovo, VPR- Veliki Preslav, VTN-Veliko Tarnovo, YKR- Yakoruda, , YMBYambol; 6- border 


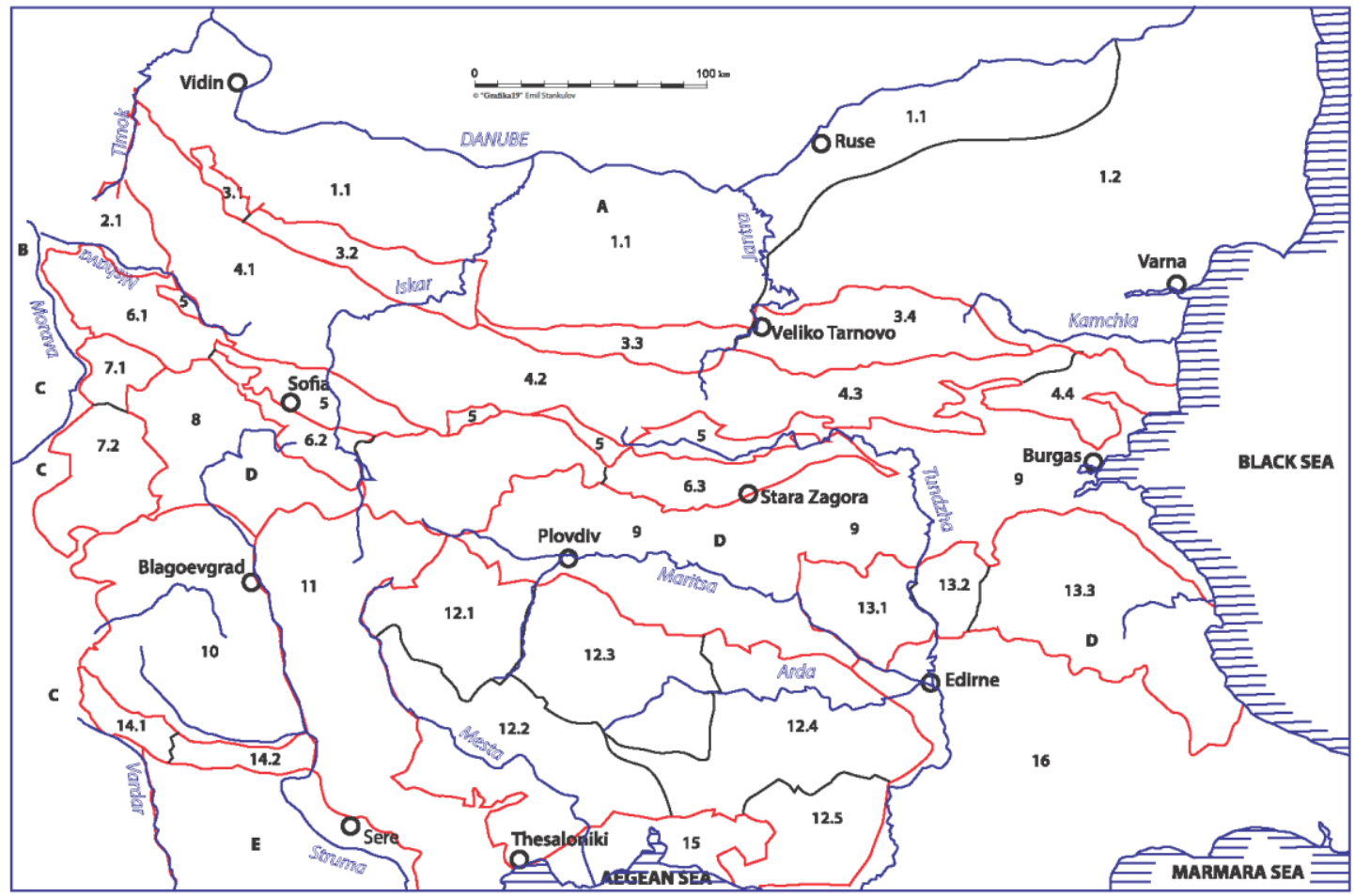

Figure 9. Overview morphotectonic map of the Balkan Peninsula East Part Abbreviations: CMP- Continental Microplate, MSZ- Morphostructural Zone, MSA- Morphostructural Area, MSL- Morphostructural Line

A - MOESIAN CMP: 1- South Moesian MSZ: 1.1. the South Peri Danube MSA, 1.2. Ludogorie MSA. 2South Carpathian MSZ: 2.1. Serbian Carpathian MSA; B - DINARIAN CMP; C - PINDIAN CMP; D BULGARIAN CMP: 3- Fore Hemus MSZ: 3.1. Belogradchik MSA, 3.2. Vratsa MSA, 3.3. Veliko Tarnovo MSA, 3.4. Veliki Preslav MSA; 4- Hemus MSZ: 4.1. West Hemus MSA, 4.2. Middle Hemus MSA, 4.3. East Hemus MSA, 4.4. Primorsko MSA; 5- Sub Hemus MSZ; 6- Srednogorie MSZ: 6.1. Suva Planina-Greben Planina MSA, 6.2. Viskyar-Lozenska Planina MSA, 6.3. Sredna Gora MSA; 7- South Morava MSZ: 7.1. Vartop MSA, 7.2. Besna Kobila MSA; 8- Kraishte MSZ; 9- Upper Thracian MSZ; 10Bregalnitsa MSZ; 11- Rila-Pirin MSZ; 12- Rhodope MSZ: 12.1. Devin MSA, 12.2. Ksanti MSA, 12.3. Smolyan MSA, 12.4. Krumovgrad MSA, 12.5. Sape MSA; 13- Sakar-Strandzha MSZ: 13.1. Sakar MSA, 13.2. Dervent MSA, 13.3. Strandzha MSA; 14- Gradesh- Belasitsa MSZ: 14.1. Gradesh MSA, 14.2. Belasitsa MSA; 15- West Thracian MSZ; 16- Lower Thracian MSZ; E- HALKIDIKIAN CMP

\section{Seismic activity}

The analysis of seismic activity along the complex morphostructural passages within the eastern part of the Balkan Peninsula is based on a free seismic catalog by data from USGS Seismic Hazard Program for the 1965-2018 statistical of period (Fig.10).

The on the fig. 10 represented seismic setting show the big differences of the earthquake activity between the Balkan Peninsula West and East Parts. The most intensive seismic activity in the south-west part of the Bulgarian Continental Microplate is a superficial effect of the transcontinental collision between the New Europe Mosaic Continental Massif and Gondwana Continental Massif. The earthquake epicenters are located mostly along the edges of the complex morphostructural passages along the border with mountain morphounits. There is little or no seismic activity in the central parts as well as within the river valley extension (kettles). 


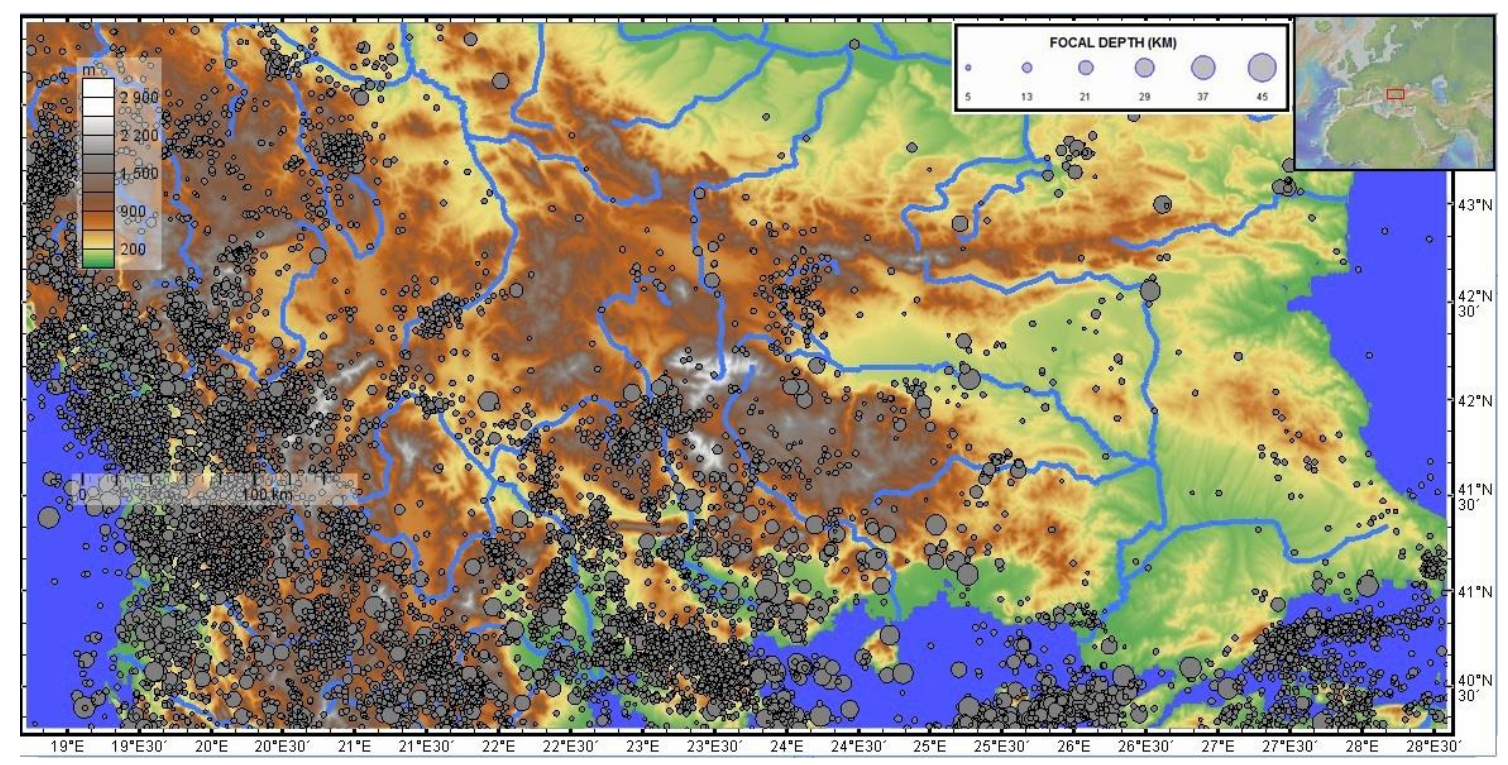

Figure 10. Seismic activity within the Balkan Peninsula for the statistical of period 1965-2018 (Seismic data source: USGS Seismic Hazard Programhttps://earthquake.usgs.gov/earthquakes/search/; Mapping tool: GeoMapApp- http://www.geomapapp.org/ )

\section{CONCLUSIONS}

The contemporary relief of the Balkan Peninsula East Part was formed during the Late Plistocene-Holocene Deformations. Their relics composed the modern regional morphostructure. The first rare role for those morphostructural processes is playing the listric tectonic effects.

The Balkan Peninsula east Part Morphogenesis was and is controlled by the current transcontinental collision between the New Europe Mosaic Continental Massif and Gondwana Continental Massif. The last one predetermined the contemporary tendency toward the positive different intensive regional movements of the earth superficia.

\section{REFERENCES}

[1] Tzankov, Tz. General aspects of the Neogene-Quaternary listric tectonics of Bulgaria. In: Global changes, vulnerability, mitigation and adaption. Fifth International conference, 17-18 April 2008, Sofia University „St. Kliment Ohridski“, Faculty of Geology and Geography, „St. Kliment Ohridski“" University Press, proceedings, Sofia, Bulgaria, 116-120, 2009.

[2] Tzankov, Tz. About the contemporary geodynamics of the Balkan Peninsula. In: Global changes, vulnerability, mitigation and adaption. Fifth International conference, 17-18 April 2008, Sofia University „St. Kliment Ohridski“, Faculty of Geology and Geography, „St. Kliment Ohridski“" University Press, proceedings, Sofia, Bulgaria, 126-128, 2009.

[3] Tzankov, Tz. \& Sv. Stankova. Borders and principal regional units of the Bulgarian Continental Micro Morphotecture (East Part of Balkan Peninsula). Acta Scientifica Naturalis, Shumen, Bulgaria, vol. 1, 218-232, 2014.

[4] Tzankov, Tz. \& Sv. Stankova. About the origin and morphostructure of the Black Sea Basin. Prosedings of the XIII Conference „Natural Sciences'2015“, September 25-27, 2015,Varna, Bulgaria, University Printing House Konstantin Preslavski University of Shumen, Bulgaria, 7476, 2015.

[5] Tzankov, Tz. \& Sv. Stankova. Post Early Pleistocene Pattern of the South Moesian Morphostructural Zone. Fourth Romanian-Bulgarian-Hungarian-Serbian Conference 
"Geographical Research and Cross-Border Cooperation within the Lower Basin of the Danube“, Vidin, Bulgaria, 21, 2016.

[6] Tzankov Tz. \& Sv, Stankova \& R, Iliev. Morphostructure of the Sakar and Strandzha Mountains. Acta Scientifica Naturalis, Volume 4, Issue 1, Febriary 2017, Bulgaria, 94-99, 2017.

[7] Tzankov Tz. \& Sv, Stankova \& R, Iliev. Morphostructure of the Rila-Pirin Mountains Range. Lap Lambert Academic Publishing. Düsseldorf, Germany, 64 p., 2017.

[8] Tzankov Tz. \& Sv, Stankova \& R, Iliev \& I. Mitkov. Survey of the Middle Struma Complex Morphostructural Passage (South-West Bulgaria). Universal Journal of Geoscience, USA, 5(6), 191-196, 2017.

[9] Tzankov Tz. \& Sv, Stankova \& R, Iliev \& I. Mitkov. Late Quaternary morphostructural generations in the eastern part of the Balkan Peninsula. SocioBrains, Bulgaria, Issue 41, 188-197, 2018. 